\title{
Photoprotective Effect of the Hydroalcoholic Extract from Red and Black Peruvian Varieties of Phaseolus vulgaris L.
}

\author{
L. Papuico-Sánchez ${ }^{1}$, M. Santa-Cruz-Ermitanio' ${ }^{1}$, Juana E. Chávez-Flores ${ }^{1}$, \\ Richard A. Solórzano-Acosta ${ }^{1,2}$ \\ ${ }^{1}$ Facultad de Farmacia y Bioquímica, Universidad Norbert Wiener, Lima, Perú \\ ${ }^{2}$ Departamento de Fitotecnia, Universidad Nacional Agraria La Molina, Lima, Perú \\ Email: andi.solorzano@gmail.com
}

How to cite this paper: Papuico-Sánchez, L., Santa-Cruz-Ermitanio, M., Chávez-Flores, J.E. and Solórzano-Acosta, R.A. (2020) Photoprotective Effect of the Hydroalcoholic Extract from Red and Black Peruvian Varieties of Phaseolus vulgaris $\mathrm{L}$. Journal of Biosciences and Medicines, 8, 46-59. https://doi.org/10.4236/jbm.2020.811005

Received: September 14, 2020

Accepted: November 6, 2020

Published: November 9, 2020

Copyright $\odot 2020$ by author(s) and Scientific Research Publishing Inc. This work is licensed under the Creative Commons Attribution International License (CC BY 4.0).

http://creativecommons.org/licenses/by/4.0/

(c) (i) Open Access

\begin{abstract}
Introduction: Ultraviolet radiation can be harmful to the skin and can create serious problems when a protective substance or equipment is not used regularly, for this reason the present study set out to evaluate the photoprotective effect of the hydroalcoholic extracts of the integument of the red and black varieties of pop beans (Phaseolus vulgaris). Materials and Method: The extracts were obtained by macerating the tegument of the two varieties of pop beans, black and red, in an ethanol/water (80:20) solution. The thin-layer chromatographic method was used to observe anti-tyrosinase activity, using the $0.05 \%$ kojic acid standard as a positive control. The photoprotective effect was evaluated in female mice of seven-week-old, Mus musculus Balb/c, with shaved back and exposed to UV-C radiation for 30 minutes once a day for thirty days to induce photo-damage in the skin. The treatments consisted in the application of extracts at $2 \%$ and $5 \% \mathrm{~W} / \mathrm{V}$ in gel on the shaved area. Only the gel formulation, sunscreen or no treatment at all was used for the control group. Acute photodamage was quantified using the Draize scale, measuring the degree of erythema and edema; and the degree of photoaging using the Glogau scale at 7 days and 30 days. Results: It was found that the ethanolic extracts of the integument of both varieties of Phaseolus vulgaris, red and black, are practically non-toxic in mice by oral and dermal routes at a limit dose of $5000 \mathrm{mg} / \mathrm{kg}$. The anti-tyrosinase effect at a qualitative level, evaluated by thin layer chromatography, showed the black variety were more active than the red one and both can be compared to the activity of the kojic acid. The two extracts of the two varieties showed photoprotective effect, however the extracts in $5 \%$ gel to a greater degree. Conclusions: It was concluded that the hydroalcoholic extract of the pop black beans tegument at $5 \%$ in gel has photoprotective effect.
\end{abstract}




\section{Keywords}

Anti-Tyrosinase Effect, Photoprotective Effect, Phaseolus vulgaris

\section{Introduction}

The solar radiation that reaches the Earth can be classified as: visible, infrared and ultraviolet light, which can also be subdivided into tree bands: UVA, UVB and UVC. This type of radiation is known to generate health problems on the skin such as premature wrinkles, blemishes and even cancer [1]. According to the World Health Organization (WHO), since the early 1970s the incidence of skin cancer has increased in the world [2] and in Peru the National Meteorology and Hydrology Service (SENAMHI) reported that in 2019 the levels of ultraviolet UVB and UVA radiation has increased between 12 and $18 \mathrm{~W} / \mathrm{m}^{2}$, considered extremely high.

For this, the defense mechanisms of the skin in a natural way are not enough, so it becomes necessary to take protective measures, using photoprotectors [3], which have encouraged the study of various plant extracts that contain phenolic compounds and flavonoids [4] as substances that can replace chemical sunscreens [5] due to their photoprotective activity without the outcome of second effects like cytotoxicity. That is the case of hydroquinone, a broad used compound with anti-tyrosinase effect which has been banned in Ghana since 2016 because of its cytotoxicity [6].

The pop bean is a species originated in the Andean central region, their seeds have high protein contain and are consumed toasted [7]. In Peru, the pop beans (Phaseolus vulgaris L.) is one of the valuable legacies of Andean agriculture, in addition, its shell is rich in polyphenolic compounds [8].

There are no antecedents that demonstrate any medicinal properties at the ethnobotanical or pre-clinical level of the pop bean; however, some of the currently recognized phytochemicals in beans are: fiber, polyphenols, phytic acid, tannins, trypsin inhibitors, and lectins. Trypsin inhibitors inhibit carcinogenesis and can be used as chemoprotective agents. Bean lectins slow the growth of nonHodgking lymphomas. Phytic acid has been shown to reduce the risk of cancer, probably due to its antioxidant power. Tannins function as effective antioxidants, anticancer, and antimutagens [9]. Then, being able to take advantage of all the phytochemical elements of the bean led us to think about the peel and its various colors, which give an indication of its richness in antioxidants and molecules with probable biological activity on the skin.

To all this, it motivates the study of the anti-tyrosinase activity and the photoprotective effect of the hydroalcoholic extract of two varieties of pop beans, aiming to offer an efficient plant nutritional base that can also be used for protection against skin-related disorders associated with ultraviolet rays. 


\section{Materials and Method}

\subsection{Extract Preparation}

The two varieties of $P$. vulgaris seeds were obtained in September 2019 in "La Parada" market in the city of Lima. Two plants of each variety were germinated for its botanic identification in the Herbarium of the Universidad Nacional Mayor de San Marcos. To obtain the extract, the seeds were soaked in $7 \mathrm{~L}$ of distilled water for 7 hours, the cotyledons were manually separated from the tegument and dried for 7 days at $40^{\circ} \mathrm{C}$. Once dry, the teguments of each variety were ground and macerated for 6 hours in a solution of ethanol/water (80:20) v/v. The extract obtained was dried, evaporating the solvent in an extractor hood and then in an oven for 3 days at $40^{\circ} \mathrm{C}$.

\subsection{Determination of Anti-Tyrosinase Activity}

The anti-tyrosinase activity was evaluated qualitatively in vitro using thin layer chromatography test (TLC), where the standard (kojic acid) and the samples of the hydroalcoholic extracts (diluted in Dimethyl sulfoxide) of the integument of the red and black varieties of pop beans was spotted in the plate. A mixture of methanol-ethyl acetate (60:40) was used as the mobile phase. The development was carried out with tyrosinase and tyrosine solutions sprayed to the plates. Colorless spots were observed on a gray-purple background [10].

\subsection{Preparation of the Extract of the Integument of the Red and Black Varieties of Pop Beans Gel for the Photoprotective Evaluation}

A 1\% Carbopol 940 colloidal suspension was prepared in distilled water for 24 hours to achieve optimal hydration, this solution had a $\mathrm{pH}$ of 3. A Nipagin/Nipasol in a $2: 1$ ratio $(0.05 \%$ Nipagin $+0.01 \%$ Nipasol $)$ solution was added as a preservative [11]. Then the dry extract of the two varieties of pop beans were weighted and incorporated so the final concentration was $2 \%$ and $5 \%$ respectively. For the incorporation of the dry extract of red pop beans, $0.6 \mathrm{~g}$ of the solid was dissolved in 4 drops of propylene glycol and incorporated into the $30 \mathrm{~g}$ of base gel, stirred until a homogeneous mixture was obtained ( $\mathrm{pH}$ 6.5).

\subsection{Implementation of UV-C Irradiation System}

A UV-C irradiation system was implemented, consisting of a Philips brand fluorescent lamp of $90 \mathrm{~cm}$ in length and 40 watts with an emission spectrum of 100 $280 \mathrm{~nm}$ with a peak of $253.7 \mathrm{~nm}$, placed in a camera $70 \times 128 \times 173 \mathrm{~cm}$ hermetically sealed with a black plastic cover to avoid contamination by UVC radiation.

\subsection{Acute Oral and Dermal Toxicity of the Hydroalcoholic Extract of the Integument of the Red and Black Varieties of Pop Beans}

All hair on the back of the Mus musculus individuals was shaved, and waited 24 hours to avoid skin irritation [12]. The extract diluted in water at a maximum 
dose of $5000 \mathrm{mg} / \mathrm{kg}$ was administered orally and topically on the shaved back of the animal, it was covered with gauze and sealed with tape for complete penetration. After four hours the gauze was removed and the animals were observed for 14 days, at the end of this period the biological samples were killed with an overdose of sodium pentobarbital $(40 \mathrm{mg} / \mathrm{kg}$ ) by intraperitoneal route. Immediately the individuals of control and exposed to the extracts of both black and red pop beans were dissected the skin of the loin exposed to the gel (portion of $2 \mathrm{~cm} \times 2$ $\mathrm{cm}$ ) as well as the liver, stomach, kidney and lung so they were deposited in a $10 \%$ buffered formaldehyde solution. The tissues were taken to the Central Laboratory of Clinical Pathology of the Hospital Nacional Arzobispo Loayza for histological analysis.

\subsection{Photoprotective Effect of the Red and Black Varieties of Pop Beans Hydroalcoholic Extract of the Integument in Mice Exposed to UVC Radiation}

The experimental mice (M. musculus Balb/ c) were acquired in the Cayetano Heredia University animal facility, they were housed in metal cages within the Norbert Wiener University animal facility, for adaptation for a week prior to the experiments, with free access to water and food, air-conditioned environment of $20^{\circ} \mathrm{C} \pm 1{ }^{\circ} \mathrm{C}$ temperature, with $55 \% \pm 5 \%$ relative humidity with 12 hours of light and 12 hours of darkness. Seven working groups were formed consisting of five mice each group: the control group (C-) without gel, the control group (C) that was applied only the skin vehicle made up of hydrophilic gel without the extract, the control group $(\mathrm{C}+)$ with sunscreen with SPF 70 and the experimental groups with $2 \% \mathrm{w} / \mathrm{v}$ and $5 \% \mathrm{w} / \mathrm{v}$ of the extract of red and black pop beans, respectively.

A dose of $5 \mathrm{mg}$ of the gel by square centimeter of skin, was applied to each of the specimens with the treatments in the shaved dorsal region and after $10 \mathrm{mi}-$ nutes they were exposed to UV-C radiation, for an interval of 30 minutes, at a 20 $\mathrm{cm}$ distance from UV-C lamp. This procedure was repeated daily for one month [13]. The photoprotective effect was evaluated based on the degrees of erythema, edema and photoaging at 7 and 30 days respectively.

\subsection{Statistical Analysis}

The values of each case were collected according to the experimental model proposed for each experimental unit (rodents). The data obtained in the trials were subjected to the analysis of variance (ANOVA), after verifying their normality and homogeneity of variances, using the Statistical Package Social Science version 24 program and at a $95 \%$ confidence level.

\subsection{Ethic Aspects}

The experimental animals were treated appropriately following the guidelines of the manual for the handling of experimental animals of the National Institute of Health of Peru. "Guide for the handling and care of laboratory animals: mice" [14]. 


\section{Results}

\subsection{Acute Oral and Dermal Toxicity of the Hydroalcoholic Extract of the Integument of the Red and Black Pop Beans Varieties}

It was found that the hydroalcoholic extracts of pop beans were "practically non-toxic" according to the Trevan scale, as no dead specimens were found at $5000 \mathrm{mg} / \mathrm{kg}$ and the damage of the evaluated organs was slight (Table 1).

In the qualitative phytochemical study of he hydroalcoholic extract [15], it was observed the presence of: quinones, flavonoids, tannins, reducing compounds, lipids, alkaloids, coumarins, leucoanthocyanidins, saponins and polysaccharides. Also, the absence of steroids, catechins and proteins was observed (Table 2).

\subsection{Anti-Tyrosinase Activity of the Red and Black Varieties of Pop Beans Hydroalcoholic Extract of the Integument by Thin Layer Chromatography}

The anti-tyrosinase activity was evaluated qualitatively by thin layer chromatography (Figure 1). On a chromatographic plate previously spotted with the extracts of red pop beans (B), black pop beans (C) and kojic acid as standard (A). Was eluted in a mixture of methanol:ethyl acetate (60:40), then a tyrosinase solution was sprayed over the entire plate and immediately the same amount of L-tyrosine solution was sprayed on the plate and allowed to incubate at temperature ambient. The inhibition of tyrosinase was observed as the appearance of colorless areas on a gray-violet background of the plate. Colorless areas were observed in the kojic acid standard (inhibition of the effect of tyrosinase by chelation of its copper ion), in the same way with the ethanolic extract of black pop beans and to a lesser extent in the ethanolic extract red pop beans. This indicates that the ethanolic extract of the black variety has a greater inhibitory capacity of the activity of the anti-tyrosinase.

Table 1. Histopathological analysis of rodent organs subjected to an acute dose of pop beans integument extract.

\begin{tabular}{|c|c|c|c|c|c|}
\hline Group & Skin & Liver & Kidney & Stomach & Lung \\
\hline Control & $\begin{array}{l}\text { Preserved skin } \\
\text { without signs of } \\
\text { toxicity }\end{array}$ & $\begin{array}{l}\text { Has congestion, } \\
\text { but no toxicity } \\
\text { is seen }\end{array}$ & $\begin{array}{l}\text { Glomeruli with } \\
\text { a low degree of } \\
\text { congestion are } \\
\text { seen }\end{array}$ & $\begin{array}{c}\text { No lesions on } \\
\text { the mucous } \\
\text { glands }\end{array}$ & $\begin{array}{c}\text { No toxicity } \\
\text { observed }\end{array}$ \\
\hline $\begin{array}{l}\text { Pop red } \\
\text { beans }\end{array}$ & $\begin{array}{l}\text { Normal } \\
\text { histophatologic } \\
\text { characteristics }\end{array}$ & $\begin{array}{l}\text { Presence of } \\
\text { erythrocytes } \\
\text { without } \\
\text { hepatocyte } \\
\text { damage }\end{array}$ & $\begin{array}{l}\text { Congested } \\
\text { glomeruli }\end{array}$ & $\begin{array}{l}\text { Mild } \\
\text { inflammation of } \\
\text { the mucous } \\
\text { glands }\end{array}$ & $\begin{array}{l}\text { Presence of } \\
\text { erythrocytes } \\
\text { and minor } \\
\text { lesions }\end{array}$ \\
\hline $\begin{array}{l}\text { Pop black } \\
\text { beans }\end{array}$ & $\begin{array}{l}\text { Thick skin with } \\
\text { increased collagen } \\
\text { and hair follicle }\end{array}$ & $\begin{array}{c}\text { Increased } \\
\text { numbers of red } \\
\text { blood cells and } \\
\text { hepatocyte } \\
\text { congestion }\end{array}$ & $\begin{array}{c}\text { Glomeruli with } \\
\text { low degree of } \\
\text { congestion and } \\
\text { presence of } \\
\text { erythrocytes }\end{array}$ & $\begin{array}{l}\text { Presence of } \\
\text { erythrocytes and } \\
\text { lesions in the } \\
\text { mucous glands }\end{array}$ & $\begin{array}{l}\text { Presence of } \\
\text { erythrocytes } \\
\text { and minor } \\
\text { lesions }\end{array}$ \\
\hline
\end{tabular}


Table 2. Results of the phytochemical study of the hydroalcoholic extract of the integument of the red and black varieties of $P$. vulgaris.

\begin{tabular}{cccc}
\hline Test/Reagent & Phytochemical & Red pop beans & Black pop beans \\
\hline Liebermann-Burchard & Steroid & - & - \\
Bortranger & Quinones & + & + \\
Assay for Cathequins & Catechins & - & - \\
Shinoda & Flavonoids & + & + \\
Ninhydrin reaction & Proteins & - & - \\
FeCl $_{3}$ & Polyphenols & + & + \\
Fehling & Reducing sugars & + & + \\
Assay for resins & Resins & + & + \\
Assay with gelatin & Tannins & + & + \\
Sudán & Lipids & + & + \\
Dragendorff & Alkaloids & + & + \\
Baljet & Coumarins & + & - \\
Mayer & Alkaloids & - & + \\
Wagner & Alkaloids & + & + \\
Rosenhein & Leucoanthocyanidins & + & + \\
Foam test & Saponins & + & + \\
Mucilage assay & Polisaccharides & + & + \\
\hline & & & + \\
\hline & & + & + \\
\hline
\end{tabular}

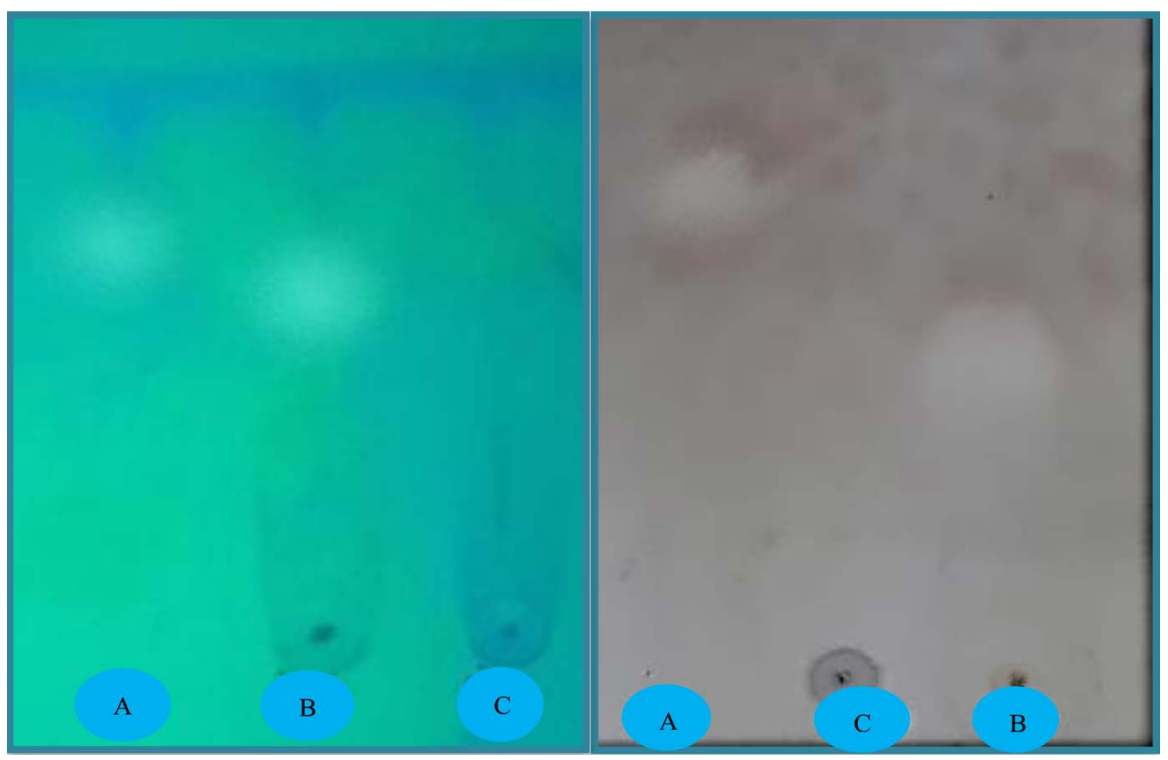

Figure 1. Anti-tyrosinase activity of red and black pop beans extracts in thin layer chromatography. A (kojic acid), B (Red pop beans extract), C (Black pop beans extract) plate chromatography eluted with methanol: ethyl acetate (60:40), observed in full light and at $366 \mathrm{~nm}$ (UV light). Discolorations on dark background.

\subsection{Photoprotective Effect of the Hydroalcoholic Integument Extract of the Two Varieties of Pop Beans in Mice Exposed to UVC Radiation 7 Days after Treatment}

Seven days after exposure to UV radiation and application of the treatments, it 
was found that the extracts of black pop beans (2\% and 5\%) and 5\% red pop beans had a lower degree of erythema and edema even compared to the control group to which sunscreen was applied. For the evaluation of photoaging, the extract of black variety presented a lower degree of statistical similarity with the control group (Table 3).

The degrees of erythema and edema were also evaluated daily during the seven days. Show that the treatment with $5 \%$ black variety not only shows a lower degree of them, but also delays the appearance of photodamage (Figure 2).

Table 3. Photoprotective effect of the extracts of red and black pop beans after seven days.

\begin{tabular}{cccc}
\hline Group & Erythema degree $^{*}$ & Edema degree $^{*}$ & Photoaging degree $^{*}$ \\
\hline Sunscreen & $2 \mathrm{~b}$ & $2 \mathrm{~b}$ & $1 \mathrm{a}$ \\
Control gel base & $4 \mathrm{~d}$ & $4 \mathrm{~d}$ & $3 \mathrm{c}$ \\
Control without gel & $3 \mathrm{c}$ & $3 \mathrm{c}$ & $3 \mathrm{c}$ \\
$2 \%$ Black pop beans & $1 \mathrm{a}$ & $1 \mathrm{a}$ & $2 \mathrm{~b}$ \\
$5 \%$ Black pop beans & $1 \mathrm{a}$ & $1 \mathrm{a}$ & $1 \mathrm{a}$ \\
$2 \%$ Red pop beans & $2 \mathrm{~b}$ & $2 \mathrm{~b}$ & $2 \mathrm{~b}$ \\
$5 \%$ Red pop beans & $1 \mathrm{a}$ & $1 \mathrm{a}$ & $2 \mathrm{~b}$ \\
\hline
\end{tabular}

*From the average of 5 repetitions, the same letters are associated with statistically similar treatments according to the Mann Whittney test $\mathrm{p}<0.05$.

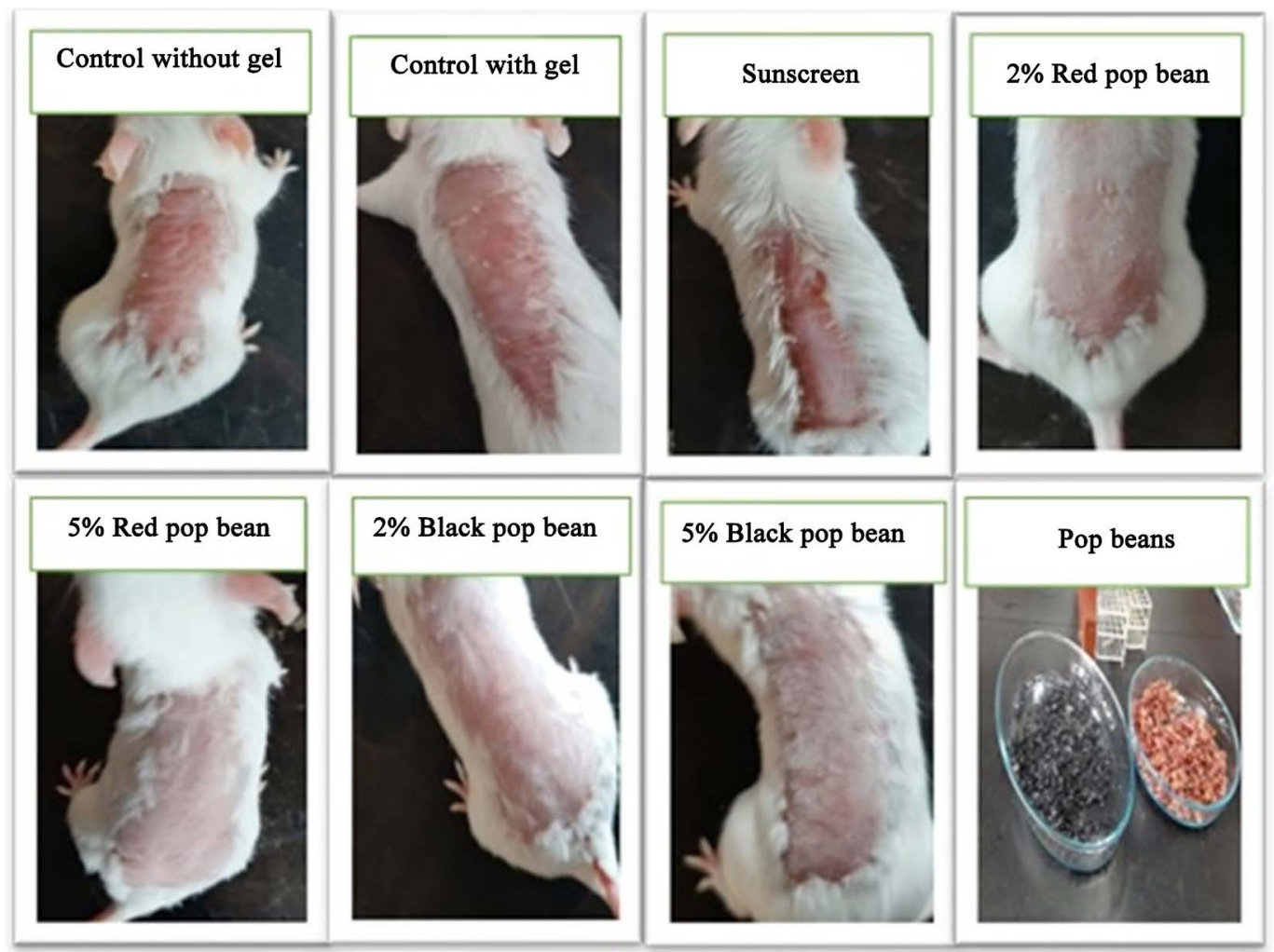

Figure 2. Macroscopic view of photodamage in Mus musculus according to experimental group at seven days and red and black varieties of pop beans. 


\subsection{Photoprotective Effect of the Integument Hydroalcoholic Extract of the Red and Black Pop Beans in Mice Exposed to UVC Radiation 30 Days after Treatment}

The degrees of erythema, edema and photoaging were analyzed in mice exposed to UVC radiation. A degree of erythema equal to zero was found in all experimental groups, which therefore was not subjected to statistical analysis. For the degrees of edema and photoaging (Table 4), it was found that in the case of edema, the extracts of black pop beans were just as efficient as the sunscreen SPF 70 ; while in the case of photoaging in this long period of 30 days, only the $5 \%$ extracts of both varieties of pop beans resulted in a lower degree, even less than the treatment with sunscreen (Figure 3).

In Figure 3 the microscopic view of the photodamage in Mus musculus is shown. In the control group without gel, the skin presented grade 3 edema and parakeratosis. In the group with sunscreen, there was slight edema at the skin level. In the treatment groups with the extract of $2 \%$ and $5 \%$ red and black pop beans, slight edema was observed and also presents hyperactivity of the hair follicle, which is why the presence of hair is observed, this is an unexpected reaction regarding its hair growth promoting effect, in general the extract showed a photoprotective effect on UVC radiation.

\section{Discussion}

Among the secondary metabolites present in various plants, polyphenolic compounds such as those found in $P$. vulgaris (Table 2) present antioxidant activity which counteract the harmful effects of oxidative stress, which is the source of several problems at the cellular level, among them damage associated with UV radiation [16] [17]. Polyphenols were not the only compounds evidenced in the pop beans integument, others such as flavonoids, tannins, alkaloids, were observed. This agree with qualitative analysis in other types of beans, specifically in cowpea bean flour (Vigna unguiculata L.), where is suggested that it can be used for the treatment of physiological disorders, to prevent cell oxidation and

Table 4. Degrees of edema and photoaging of the integument hydroalcoholic extract of the red and black varieties of $P$. vulgaris in radiation-induced mice.

\begin{tabular}{ccc}
\hline GROUP & EDEMA DEGREE & PHOTOAGING DEGREE $^{*}$ \\
\hline Sunscreen & $0.6 \mathrm{a}$ & $2.4 \mathrm{c}$ \\
Control gel base & $2.0 \mathrm{~b}$ & $3.0 \mathrm{~d}$ \\
Control without gel & $2.2 \mathrm{~b}$ & $3.0 \mathrm{~d}$ \\
$2 \%$ black pop bean & $0.2 \mathrm{a}$ & $2.0 \mathrm{~b}$ \\
$5 \%$ black pop bean & $0.6 \mathrm{a}$ & $1.0 \mathrm{a}$ \\
$2 \%$ red pop bean & $0.2 \mathrm{a}$ & $2.0 \mathrm{~b}$ \\
$5 \%$ red pop bean & $2.0 \mathrm{~b}$ & $1.0 \mathrm{a}$ \\
\hline
\end{tabular}

*From the average of 5 repetitions, the same letters are associated with statistically similar treatments according to the Mann d Whittney test $\mathrm{p}<0.05$. 

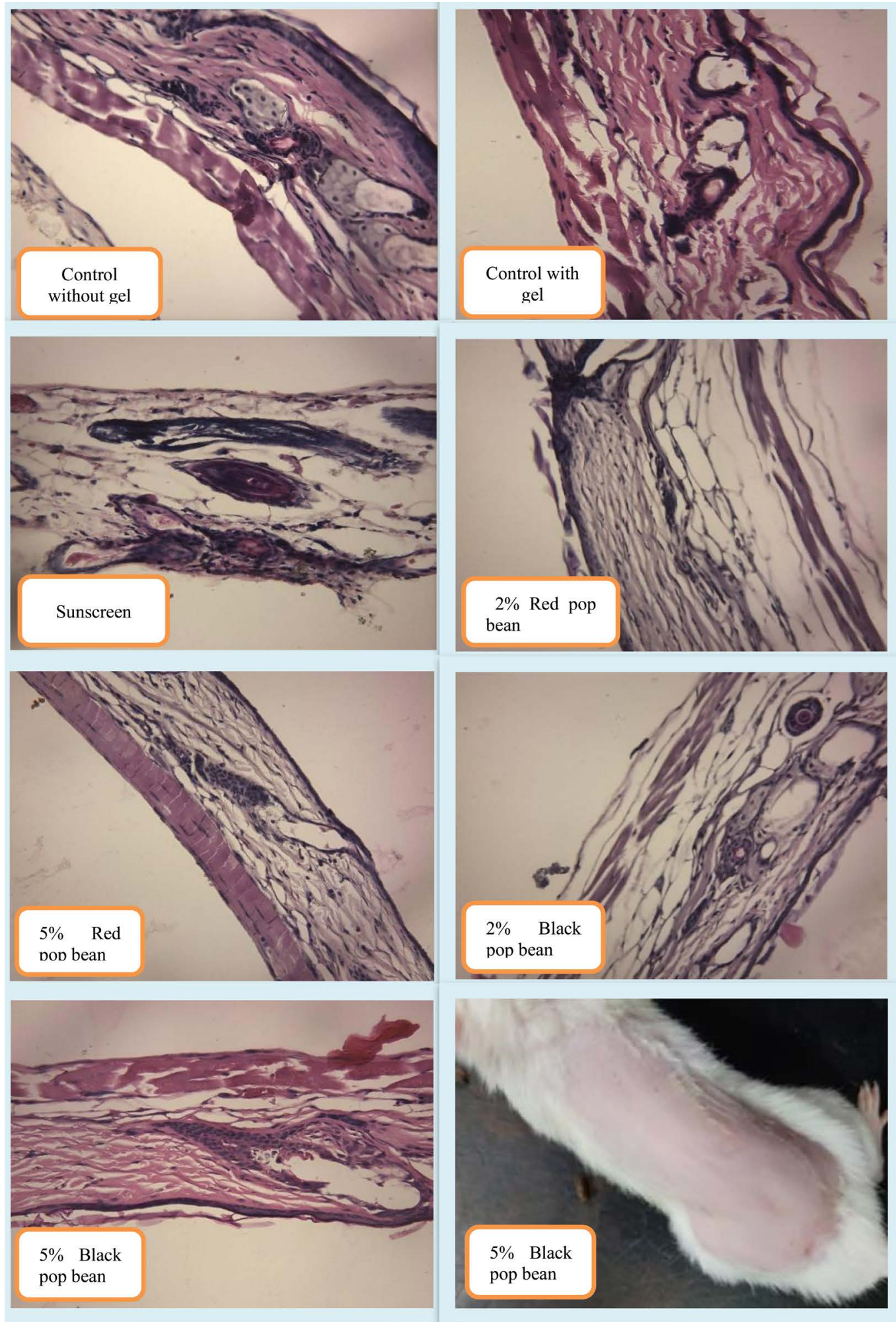

Figure 3. Microscopic view of photodamage in Mus musculus according to experimental group in histopathological sections of skin.

protecting cells from carcinogenesis [18] [19].

Of all these compounds, the most active and abundant seem to be polyphenols 
and the highest phenol contents were quantified in the black testa variety, followed by the red one, with statistical differences between them, and to a lesser extent the white testa variety [20]. Therefore, the results found when carrying out the preliminary phytochemical qualitative analysis bear some similarity with the secondary metabolites found in previous studies.

In this study, the anti-tyrosinase activity was evaluated and according to the results, the ethanolic extracts of the Phaseolus vulgaris variety used showed inhibitory capacity of the tyrosinase enzyme in a development by thin layer chromatography. At present it is known that the most important stimulus for melanogenesis is ultraviolet radiation [21] and that polyphenols of plant origin affect the biosynthesis of melanin [22] [23]. Apparently, with respect to polyphenols, among their many properties is the inhibitory activity of tyrosinase and one of the mechanisms is to competitively inhibit tyrosinase due to its ability to chelate copper in the active site, which leads to irreversible tyrosinase inactivation [24].

The various skin disorders including skin cancer are caused by overexposure to solar radiation, particularly the ultraviolet (UV) component [25]. It is known that $5 \%$ of the UV radiation received by the earth is composed of UVB radiation [26] and it is the most active component of solar radiation, responsible for a wide variety of skin diseases, including melanoma and non-melanoma skin cancer. Other damage known from the exposition to UV radiation can induce DNA damage, oxidative stress, premature skin aging and can act as a tumor initiator and co-carcinogen [27] [28].

On the other hand, UVA ultraviolet radiation constitutes between $90 \%$ and $95 \%$ of the solar radiation that reaches the surface of the earth and due to its longer wavelength, it has a high capacity to penetrate the skin, this leads to generation of reactive oxygen species (ROS) that can cause damage at the level of cellular proteins, lipids and DNA [27]. Both UVB and UVA ultraviolet radiation are responsible for up to $90 \%$ of the changes commonly attributable to aging [29].

The results obtained showed that the extracts of black pop beans (2\% and 5\%) and red pop beans $5 \%$ presented a lower degree of erythema and edema in the individuals studied. Regarding photoaging, the extract of black pop beans presented a lower degree of statistical similarity with the control group ( $\mathrm{p}$ value $<$ 0.05). The degrees of erythema and edema were also evaluated daily for seven days, in which it stands out that the treatment with $5 \%$ black pop beans not only shows a lower degree of skin damage, but also delays the appearance of photodamage.

The results found agree with the evaluation of other vegetal extracts, such as the anthocyanic extract of Zea mayz "purple corn", where the evaluated acute and subacute photodamage and photoaging induced by UVC radiation were shown to have a photoprotective effect against the harmful activity of UVC radiation [7]. Various investigations have shown the correlation between the increase in UVR, visible and far infrared radiation and the production of anthocyanins (photo-induction) as a mechanism used by plants to prevent oxidative 
damage by radiation [30] [31]. Like Tarquino [8] who evaluated in vitro the photoprotective activity of phenolic extracts from 4 varieties of quinoa in which he determined that the variety of quinoa Ajara (black) had a higher content of phenolic compounds that absorb in the range of UVA and UVB radiation.

The results also showed some damage in the group that applied the base cream free of the extracts. This can be justified according to Ishiwatari et al., who mention that preservatives such as methylparaben and propylparaben intervene in the physiology of the skin by inhibiting the production of hyaluronic acid and type $\mathrm{V}$ collagen, which are found in the basal layer of the skin providing hydration, proliferation and differentiation of the epidermis and by decreasing their production, deterioration and aging of the skin occurs. The mechanism of these preservatives is to accumulate on the epidermis, affecting keratinocytes, which triggers a series of unfavorable changes on the skin [32].

Similarly, Osamu et al. determined that methylparaben can have harmful effects on the skin at $0.3 \%$ concentrations and can present a synergism of toxicity since radiation triggers a series of unfavorable biochemical reactions for the skin [33].

\section{Conclusion}

The present findings show that the pop bean extract provides excellent photoprotection of the skin, probably due to its antityrosinase and radical scavenging activity of its active components, which is why the importance of dietary phytochemical supplements to combat aging and skin disorders. The use of natural chemopreventive agents may be a new alternative for protection against exposure to ultraviolet radiation. This is particularly interesting regarding the extract of the black variety; Therefore, the shell as a by-product of the industrial processing of pop bean as a snack, could be used as a low-cost ingredient with a high added value in the cosmetic and pharmaceutical field for photoprotective applications. It is recommended to investigate the nature of the components of the pop bean extract.

\section{Acknowledgements}

To Adriana del Valle for her support in the translation and revision.

\section{Conflicts of Interest}

The authors declare no conflicts of interest regarding the publication of this paper.

\section{References}

[1] Arellano, I., Alcalá, D., Barba, J.F., Carlos, B., Castanedo, J.P., Barreda, F., et al. (2014) Recomendaciones clínicas para la fotoprotección en México. Dermatología $C M Q$, 12, 243-255. https://www.medigraphic.com/pdfs/cosmetica/dcm-2014/dcm144e.pdf

[2] World Health Organization (2003) Organización, Salud Programa, Mundial Unidas, 
Naciones Comisión, Medio Ambiente Índice UV Solar Mundial. UV Index. http://www.who.int/uv

[3] Díaz, E., Castillo, M.D., Sabates, M., Curbelo, M. and Ramos, N. (2005) Radiación Ultravioleta. Fotoenvejecimiento cutáneo. MediSur, 3, 14-33.

https://www.redalyc.org/articulo.oa?id=180020172002

[4] Doroteo, V.H., Díaz, C., Terry, C. and Rojas, R. (2013) Compuestos fenólicos y actividad antioxidante in vitro de 6 plantas peruanas. Revista de la Sociedad Química del Perú, 79, 13-20. http://www.scielo.org.pe/pdf/rsqp/v79n1/a03v79n1.pdf

[5] Moya Cahuana, T.M. and Osorio Oscco, R.I. (2017) Actividad fotoprotectora de formulación tópica a base del extracto hidroalcohólico de Fragaria vesca L. (fresa). http://cybertesis.unmsm.edu.pe/bitstream/handle/20.500.12672/6878/Moya ct.pdf? sequence $=2$

[6] Naima, P., Ayesha, S. and Sharique, A. (2019) On the Intricacies of Facial Hyperpigmentation and the Use of Herbal Ingredients as a Boon for Its Treatment: Cosmeceutical Significance, Current Challenges and Future Perspectives. IntechOpen, London.

[7] Myers, J.R. and Kmiecik, K. (2017) Common Bean: Economic Importance and Relevance to Biological Science Research. In: de la VegaMarta, M., Santalla, M. and Marsolais, F., Eds., The Common Bean Genome, Springer, Cham, 1-20. https://doi.org/10.1007/978-3-319-63526-2 1

[8] Centro Nacional de Comunicaciones Biomédicas Lister Hill (2020) Biblioteca Nacional de Medicina de EE. UU. Guía para entender Condiciones genéticas. Genetics. https://ghr.nlm.nih.gov/gene/TYR

[9] Ulloa, J.A., Rosas, P., Ramírez, J. and Ulloa, B. (2011) El frijol (Phaseolus vulgaris): su importancia nutricional y como fuente de fitoquímicos. CONACYT, Mexico.

[10] Condo, M.E. and Quispe Campo, J.M. (2019) Evaluación del efecto anti-tirosinasa del extracto metanólico y etilacetato de Citrus sinensis (naranja). Universidad Nacional Mayor de San Marcos, Lima.

https://cybertesis.unmsm.edu.pe/bitstream/handle/20.500.12672/11311/Condo rm. pdf? sequence $=3 \&$ is Allowed $=y$

[11] De Souza, C., De Souza, R. and De Lima, A. (2018) Elaboração de Géis e Análise de Estabilidade de Medicamentos.

https://paginas.uepa.br/eduepa/wp-content/uploads/2019/06/MANUAL-BASICOGEIS.pdf

[12] Quispe, N.H. and Blacido, Z.J. (2018) Actividad cicatrizante y toxicidad dérmica del extracto etanólico de los tubérculos de Ullucus tuberosus caldas "olluco" en animales de experimentación. Universidad Norbert Wiener, Lima. http://repositorio.uwiener.edu.pe/handle/123456789/1734

[13] Seijas, P.A. (2010) Efecto fotoprotector del extracto antociánico de Zea mays var canteño "maíz morado" en piel de Mus musculus var. Balb/C ante el fotodaño agudo, subagudo y fotoenvejecimiento inducido por radiación UV-C. Universidad Nacional de Trujillo, Trujillo.

http://dspace.unitru.edu.pe/bitstream/handle/UNITRU/1059/TESIS\%20DOCTORA DO.SEIJAS.pdf? sequence $=1$ \&isAllowed $=\mathrm{y}$

[14] Fuentes, F., et al. (2010) Guía de manejo y cuidado de animales de laboratorio: Ratón. Instituto Nacional de Salud, Lima.

[15] Lock, O. (1994) Investigación fitoquímica. Métodos en el estudio de productos naturales. 2 da Ed, Fondo Editorial de la Pontificia Universidad Católica del Perú, Lima. 
[16] Paladino, S. and Zuritz, C. (2011) Extracto de semillas de vid (Vitis vinifera L.) con actividad antioxidante: eficiencia de diferentes solventes en el proceso de extracción. Revista de la Facultad de Ciencias Agrarias, 43, 187-199.

https://www.researchgate.net/publication/262612597 Extracto de semillas de vid Vitis vinifera L con actividad antioxidante eficiencia de diferentes solventes en el proceso de extraccion

[17] García, B., Saldaña, A. and Saldaña, L. (2013) El estrés oxidativo y los antioxidantes en la prevención del cáncer. Revista Habanera de Ciencias Médicas, 12, 187-196. http://scielo.sld.cu/pdf/rhcm/v12n2/rhcm05213.pdf

[18] Vargas, Y. and Villamil, O. (2012) caracterización fisicoquímica y nutricional de la harina de frijol caupí (Vigna unguiculata L.) cultivado en el departamento del Tolima. Universidad del Tolima, Tolima. https://www.redalyc.org/pdf/1698/169823914099.pdf

[19] Olivo, E. (2015) Caracterización fitoquímica de la fracción hipoglucemiante aislada del extracto acuoso de la vaina del frijol (Phaseolus vulgaris L.), Instituto Politécnico Nacional, México.

https://tesis.ipn.mx/jspui/bitstream/123456789/18722/1/proyecto\%20de\%20invesiga cion EOP.pdf

[20] Diaz, M. (2011) Incidencia de Rhizoctonia spp., Sclerotium rolfsii y Macrophomina phaseolina en frijol común en villa clara. Universidad Central "Marta Abreu” de las Villas, Santa Clara. http://dspace.uclv.edu.cu/bitstream/handle/123456789/3579/Manuel\%20Diaz\%20C astellanos\%20-\%20Tesis\%20Doctoral\%5b1\%5d.pdf?sequence=1\&isAllowed $=\mathrm{y}$

[21] Sarkhail, P., Salimi, M., Sarkheil, P., Heidarnezhad, F. and Saeidnia, S. (2017) Evaluación de las actividades antimelanogénicas y citotóxicas de Phlomis caucasica en células de melanoma humano SKMEL-3. International Journal of Cáncer Management, 10, e4633. https://doi.org/10.5812/ijcm.4633

[22] Ortiz-Ruiz, C.V., Garcia-Molina, M. del M., Serrano, J.T., Tomas-Martinez, V. and Garcia-Canovas, F. (2015) Discriminación entre sustratos alternativos e inhibidores de la tirosinasa. Revista de Química Agrícola y Alimentaria, 63, 2162-2171. https://doi.org/10.1021/jf5051816

[23] Austin, A., Calderón, M., Martínez, A. and Ortiz, J. (2015) Actividad anti-tirosinasa de ocho especies de plantas nativas de Mesoamérica usadas en aplicación dérmica. Universidad San Carlos Guatemala, Guatemala.

http://biblioteca.usac.edu.gt/tesis/06/06 3715.pdf

[24] Kim, Y.J. and Uyama, H. (2005) Inhibidores de la tirosinasa de fuentes naturales y sintéticas: estructura, mecanismo de inhibición y perspectiva para el futuro. Cellular and Molecular Life Sciences, 62, 1707-1723. https://doi.org/10.1007/s00018-005-5054-y

[25] Svobodova, A., Walteroba, D. and Vostadora, J. (2006) Ultraviolet Light Induced Alteration to the Skin. Biomedical Papers of the Medical Faculty of the University Palacky, Olomouc, Czechoslovakia, 150, 25-38.

[26] Kullavanijaya, P. and Lim, H.W. (2005) Photoprotection. Journal of the American Academy of Dermatology, 52, 937-958. https://doi.org/10.1016/j.jaad.2004.07.063

[27] Ichihashi, M., Ueda, M., Bydiyanto, A., Bito, T., Oka, M., Fukunaga, M., et al. (2003) UV-Induced Skin Damage. Toxicology, 189, 21-39. https://doi.org/10.1016/S0300-483X(03)00150-1

[28] Afaq, F. and Katiyar, S.K. (2011) Polyphenols: Skin Protection and Inhibition of Photocarcinogenesis. Mini-Reviews in Medicinal Chemistry, 11, 1200-1215. 
https://doi.org/10.2174/13895575111091200

[29] Tamaka, M., Komaya, Y. and Nomura, Y. (2009) Effects of Collagen Peptide Ingestion on UVB-Induced Skim Damage. Biotechnology and Biochemistry, 73, 930-932. https://doi.org/10.1271/bbb.80649

[30] Zhou, Y.H., Zhang, Y.Y., Zhao, X., Yu, H.J., Shi, K. and Yu, J.Q. (2009) Impact of Light Variation on Development of Photoprotection, Antioxidants, and Nutritional Value in Lactuca sativa L. Journal of Agricultural and Food Chemistry, 57, 54945500. https://doi.org/10.1021/jf8040325

[31] Morales, L.O., Tegelberg, R., Brosché, M., Lindfors, A., Siipola, S. and Aphalo, P.J. (2011) Temporal Variation in Epidermal Flavonoids Due to Altered Solar UV Radiation Is Moderated by the Leaf Position in Betula pendula. Physiologia Plantarum, 143, 261-270. https://doi.org/10.1111/j.1399-3054.2011.01511.x

[32] Ishiwatari, S., Suzuki, T., Hitomi, T., Yoshino, T., Matsukuma, S. and Tsuji, T. (2007) Effects of Methyl Paraben on Skin Keratinocytes. Journal of Applied Toxicology, 27, 1-9. https://doi.org/10.1002/jat.1176

[33] Osamu, H., Kokura, S., Adachi, S., Takagi, T., Naito, Y, Tanigawa, T., et al. (2006) Methylparaben Potentiates UV-Induced Damage of Skin Keratinocytes. Toxicology, 227, 62-72. https://doi.org/10.1016/j.tox.2006.07.018 